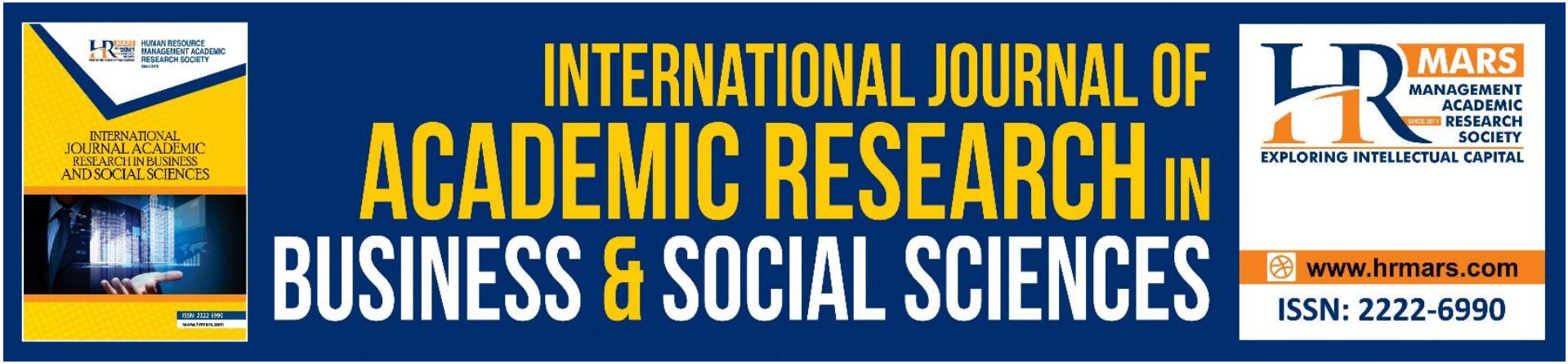

\title{
Malay Thought in the Novel Klon by Idris Boi
}

\section{Rosnani Md Zain, Nik Rafidah Nik Muhamad Affendi}

To Link this Article: http://dx.doi.org/10.6007/IJARBSS/v11-i11/11368

DOI:10.6007/IJARBSS/v11-i11/11368

Received: 20 October 2021, Revised: 30 October 2021, Accepted: 01 November 2021

Published Online: 02 December 2021

In-Text Citation: (Zain \& Affendi, 2021)

To Cite this Article: Zain, R. M., \& Affendi, N. R. N. M. (2021). Malay Thought in the Novel Klon by Idris Boi. International Journal of Academic Research in Business and Social Sciences, 11(11), 2020-2029.

\section{Copyright: @ 2021 The Author(s)}

Published by Human Resource Management Academic Research Society (www.hrmars.com)

This article is published under the Creative Commons Attribution (CC BY 4.0) license. Anyone may reproduce, distribute, translate and create derivative works of this article (for both commercial and non0-commercial purposes), subject to full attribution to the original publication and authors. The full terms of this license may be seen at: http://creativecommons.org/licences/by/4.0/legalcode

Vol. 11, No. 11, 2021, Pg. $2020-2029$

Full Terms \& Conditions of access and use can be found at http://hrmars.com/index.php/pages/detail/publication-ethics 


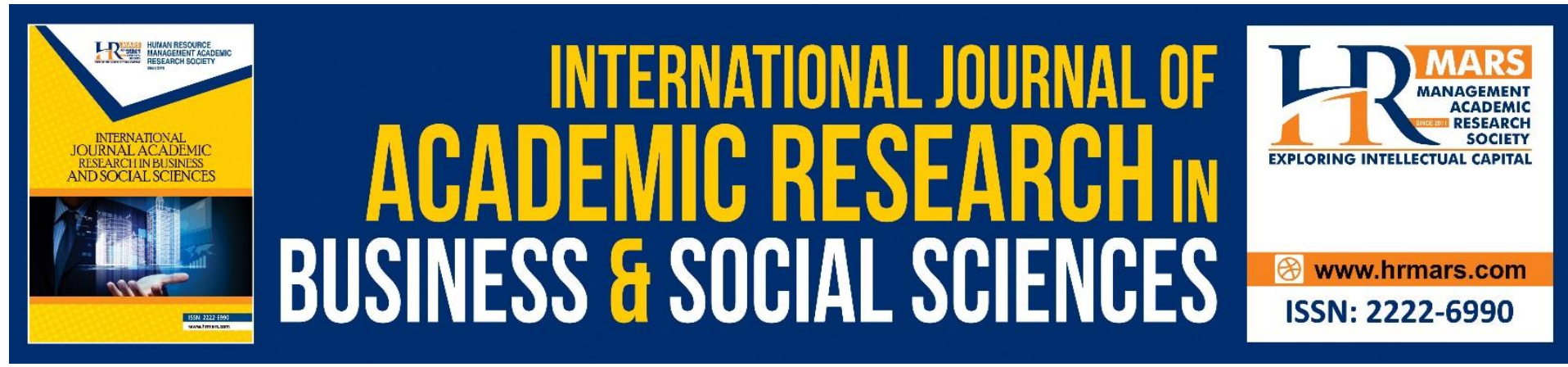

\title{
Malay Thought in the novel Klon by Idris Boi
}

\author{
Rosnani Md Zain, Nik Rafidah Nik Muhamad Affendi \\ Department of Malay Language, Faculty of Modern Languages and Communication \\ Universiti Putra Malaysia, 43400 Serdang, Selangor \\ Email: nanieyzain@gmail.com, nrafidah@upm.edu.my
}

\begin{abstract}
This paper discusses the Malay thought in the novel Klon (2015) by Idris Boi. In general, thought is the central focus or the main idea of the author in a literary work that covers all aspects of human life whether it be social, political, economic or other fields. As a social documentation tool, science and technology fiction novels are no exception when it comes to recording the life of the Malay community from various dimensions, especially in the aspects of science and technology that can be seen through the author's thoughts. This study is based on the views of scholars who claim that science fiction novels do not reflect the thinking of the Malay community. Thus, the problem needs to be resolved through two research objectives, namely classifying and analyzing the Malay thought found in the novel Klon (2015). Methods of library research and text analysis as well as the application of 4K Integrated Thinking System (SPB4K) theory generated by Mohd. Yusof Hasan is used as the theoretical foundation in this study. The results of this study found that there are several aspects of Malay thought displayed such as in the aspects of religion, education and identity. The study concludes that the novel Klon (2015) displays numerous Malay thoughts from various dimensions.
\end{abstract}

Keywords: Thought, Malay, Klon, Science Fiction, SPB4K

\section{Introduction}

Literature and society are closely related to each other. This is because literature depicts tales of society that stems from the manifestation of society's life in the real world. Because literature is born with society, it too developed with the passage of time. This is clearly stated by Shahnon (1987) in which, "... perceiving this advantage in particular correlates with its distinct connection to society. A novel is a social documentation. Its content is also the content of the community. The author lives in the midst of the values of his community. He describes the struggle in life, the conflict between justice and injustice, mixing the thoughts and feelings of his people, mixed with his imagination which is also indirectly the imagination of society". Additionally, Wellek and Warren (1988) also stated that, 'Literature is the social documentation of a society and is used by historians as a medium in order to learn about a society.'

In relation to that, science fiction novels as a social documentation tool are also no exception in displaying the life of the Malay community through aspects of thought presented by the 
author. The definition of thought as recorded in the Fourth Edition Hall Dictionary (2005) is about thinking and how to solve problems. This is also in line with the opinion of Farra and Rafidah (2016) which stated that thinking refers to a process of using the mind to find meaning and steer the solution of a doubt or problem that arises towards a positive or negative solution.

Meanwhile, according to Wan's (2010) definition of Malay, the present day term or usage of the word 'Malay' has three meanings and is used within different contexts. The first meaning is often used in the context of Indonesia, namely the Malays as one of several tribes or ethnic groups alike the Javanese, Bugis, Makasar, Bali, Mandailing, Batak, Korinchi, Banjar, Rawa, Limpong, Minangkabau, Boyan, Madura, Patani, Manado, Toraja and so on. This Malay meaning is still used in Indonesia which refers to those who live in the Riau Islands and the east coast of Sumatra and speak Riau Malay as the national language of the Indonesian nation state. The second meaning is as enshrined in the Malaysian Constitution, namely those who have three main characteristics as follows; that is, someone who speaks and makes Malay their first language, is Muslim and adheres to the customs that are commonly practiced by the Malays.

The third interpretation of 'Malay' denotes a large group of nations or races or a 'cluster of nations'. It is a term used by researchers in the fields of anthropology and socio-linguistics; also used by UNESCO to refer to the original inhabitants of the Peninsular and the Malay Archipelago which is now better known as the Malay World. It is a cultural conception that does not make being Muslim as part of the Malay definition, corresponding to how Filipinos, Batak or Balinese ethnicities or the original inhabitants of Taiwan Island are categorized under 'Malay clusters'. One of the elements in common is that they speak a language from a branch or clump of Austronesian or Malayo-Polynesian mother tongues.

Based on the definitions of 'thought' and 'Malay' as stated, the researcher concluded that Malay thought in the context of the study of science fiction novels refers to the ideas presented by the author through stories set in the Malay world. Therefore, Malay thought also includes aspects such as religion, education, patriotism and wisdom.

This study also stems from the view of Nisah (2014) who stated that the direct imitation of the West's framework including the Western society's way of thinking into Malay science fiction novels causes the novels produced to look awkward and out of place in the context of Malay life. Based on this statement, a pilot study needs to be conducted in order to resolve the research problem on whether it is true that science fiction novels do not highlight the thoughts of the Malay community as claimed by literary critics?

\section{Objectives}

- Classify the Malay thought found in the novel Klon by Idris Boi.

- Analyze the Malay thought found in the novel Klon by Idris Boi.

\section{Literature Review}

This literature review is done by highlighting previous studies that touch on the aspects of Malay thought in literary works and science fiction novels. Previous studies have found that aspects of Malay thought have formerly been studied by past researchers. Among them, 
findings in the study by Normaizatul and Halis (2019) titled "Pemikiran Islam Dalam Konteks Sosioekonomi Dalam Kumpulan Cerpen Cahaya Pelita Nurani" show that some socioeconomic aspects are found in the collection of short stories such as the issue of poverty, oppression, equality of rights, development, employment opportunities and urbanization. Next, a study by Noor and Salmah (2019) titled "Pemikiran dalam Novel Siber Kasih Darmia dari Aspek Teori Estetika Bersepadu" finds that this novel displays Malay thinking that centres on the aspect of love, namely love for family, friends and neighbors. Malay thought has also been explored by Farra and Rafidah (2016) in "Pemikiran Kerohanian Dalam Cerpen KanakKanak Pilihan Mutakhir Dan Kesan Positif Kepada Kanak-Kanak". This study found that children's short stories which display spiritual conceptions that involve human relationships with Allah and human relationships among human beings deliver a positive impact on children, meanwhile, Nurul (2015) carried out a study entitled "Pemikiran Islam dalam 'Ayn karya Kemala" in which it found the Malay thought associated with Islam are thoughts concerning faith, syariah and morality.

Based on the highlights of previous studies, it is undeniable that various studies regarding Malay thought have been performed by previous researchers. Be that as it may, previous studies were more focused on the economic, social and religious aspects. In terms of material selection, it seems that previous researchers favored the genres of short stories, children's literature, cyber novels and adult novels in examining aspects of Malay thought. On that account, the researcher perceives a gap in research to study science fiction novels, especially in regards to the aspect of Malay thought.

\section{Research Methodology}

This study utilizes library research, text analysis and the application of $4 \mathrm{~K}$ Integrated Thinking System theory. Library research was used to examine the reports and references relevant to the study. Meanwhile, the method of text analysis was used to examine the thoughts of the Malay community found in the text based on the objectives of the study that have been outlined by the researcher. For that, the researcher has chosen the novel Klon as the research material. Klon is a science and technology fiction novel produced by Idris Boi in 2015 under the publishing company Utusan Publications \& Distributions Sdn. Bhd. This novel won third place in the Science and Technology Fiction Novel Writing Competition organized by Universiti Teknologi Malaysia (UTM) in collaboration with Utusan Group. This novel tells the story of Malaysians and their struggle in going against human cloning activities. Seen through the perspective of Dr. Fakiruddin, a Malay-Muslim scientist who strongly adheres to the teachings of Islam, he rises up against impiety and does not submit to the death threats sent by the United States. This is because he keeps confidential documents regarding the illegal practice of human cloning carried out in the company he works for. At the same time, Dr. Fakiruddin did not want to conspire with the United States and assist with carrying out their mission of producing human clones with the aim to conquer the world under the New World Order and Freemason agenda.

Furthermore, this study also uses the 4K Integrated Thinking System (SPB4K) theory generated by Mohd. Yusof Hasan as a research basis. SPB4K theory is a theory in which spiritual thinking are thoughts that are founded from aspects of divinity and faith. This thought oversees humans' relationship with Allah, their fellow human beings, as well as nature. Binary thinking is a form of thinking related to the development of the human brain 
that leads to skills of excellence, glory, resourcefulness and ingenuity. Creativity Thinking is a form of thinking that values the construction of new ideas, innovation in the development of production and marketing systems, problem solving and decision making as well as data analysis from various angles to obtain useful information and finding ways to narrow differences of opinion. Creativity thinking also emphasizes the aspects of art, beauty and elegance. For example, the use of creative thinking is to focus on the aspects of beauty in literary works such as language style, storytelling techniques and so on. On the other hand, Scientific Thinking refers to a form of thoughts geared towards science and technology that emphasizes scientific, factual, numerical, accurate, objective, literal and concrete aspects.

\section{Research Analysis and Discussion \\ Malay Thought in the Aspect of Religion}

Etymologically, the term 'keagamaan' (religion) comes from the word "agama" which has the prefix "ke" and the suffix "an" that comes together to form the word 'keagamaan' (Kamus Dewan Fourth Edition, 2005). In relation to this, Poerwadarminta (1986) gives the meaning of religion to be the attributes found in religion or everything surrounding religion, such as religious feelings, or religious matters. Thus, in the context of this study, religion refers to mankind's relationships or responsibilities in matters of religion such as man's relationship with Allah as well as their fellow human beings.

According to Farra and Rafidah (2016), a person's relationship with Allah includes responsibility, trust and their obedience to Allah. The word 'responsibility' is defined as an obligation that must be performed by all regardless of gender according to the function of its occurrence. This means that human beings must recognise that their purpose of existence is to act as servants of Allah and caliphs to nature. Therefore, man's duty to Allah is to devote all their attention, care, compassion and actions to all that is good.

Man's relationship with Allah is clearly evident in the novel Klon (2015) by Idris Boi. This can be seen through the portrayal of the character Dr. Fakiruddin who practices amar makruf (encouraging good) and nahi mungkar (forbidding wrong) throughout his life. The brave Dr. Fakiruddin dares to oppose the cloning activities carried out by the United States in his workplace. Although he is alone in the country, he prevents evil by not conspiring with their schemes. In fact, he was brave enough to expose the heinous act to the Malaysian Embassy in the United States by attaching the evidence obtained in the confidential document. The situation clearly depicts Dr. Fakiruddin as a devout servant of Allah who strongly maintains his relationship with Allah. Furthermore, Dr. Fakiruddin understood that Islam strictly forbids human cloning. The passage below describes the situation:

"It will wreak havoc upon the world. Not to mention trying to deny the might of God ", said Dr. Fakiruddin. He flipped through the document in his hand.

(Klon: 210)

Based on the passage above, Dr. Fakiruddin's character is in line with the opinion of Mohd (2007) who stated that every Muslim should inculcate religious thinking within themselves. This way of thinking will increase one's faith, integrity, belief and their submission to the power of Allah. Therefore, with the strength of divine thinking, the Malay community is able to become virtuous people who practice amar makruf nahi mungkar. The result of nurturing 
this way of thinking will produce a Malay community, or more accurately in the context of this study, a Malay-Muslim scientist who devotes himself to his religion as illustrated through the character of Dr. Fakiruddin.

On top of obeying Allah's commandments, humans also need to maintain good relations with each other. Maintaining good relations among human beings whether it be through words or actions. In respect to verbal communication, Muslims are encouraged to speak with their surrounding community using polite, kind language and avoid words that can hurt the feelings of others. Meanwhile, in terms of actions, Muslims are highly encouraged to visit each other during festivities, greet each other all while respecting each other and so on.

This is evidenced in the novel Klon (2015) by Idris Boi, the author displays many human relationships from various angles. Among them are a child's relationship with their parents, an employer's relationship with their employees and the relationship of Muslims with nonMuslims. In the novel, the relationship between a child and their parent can be seen through the description of the character of Dr. Fakiruddin who is an obedient child to his parents. Despite working far away from family, he always calls them to say hello. As an employer, Dr. Fakiruddin is a good leader who does not look down on his employees of different religions and always celebrates differences of opinion. Relationships with non-Muslims can be seen through the actions of Dr. Fakiruddin who consistently respects them in spite of their difference in religious beliefs. This clearly shows that Dr. Fakiruddin regularly practices spiritual thinking within himself as Allah's humble servant, obedient to His command in maintaining human relationships (Mohd, 2007). In accordance with that, Rafidah, Saniah and Arba'ie (2010) were correct in stating that Malay literary works clearly reflect the Malay world-view. The Malays' outlook on life is moderately concerned with good relations between their fellow human beings, the natural world as well as his supernatural or metaphysical world. This can be seen through the passage below:

\begin{abstract}
Although Dr. Fakiruddin was a leader, he had never considered himself greater and more important than others. On the contrary, Dr. Fakiruddin considers them all to be equal. He never discriminated in terms of his treatment towards them. Whether they were of high or low rank, it was all the same to him. As a result, Dr. Fakiruddin is well liked and widely respected by the staff in his department.
\end{abstract}

(Klon: 80-81)

\title{
Malay Thought in the Aspect of Education
}

Next, Malay thought can also be seen from a pedagogy standpoint. According to Dewey (1916), education is a process of experience. This is because life is a process of growth, so education means to aid human growth without the limitation of age. The process of growth is the practice of adaptation at every stage and raising competence in one's development through education. Next, education is the capability to guide inexperienced human beings towards adulthood. Education is also defined as the effort to achieve independence and responsibility (Mochtar, 1994). For Kneller (1964), education is a task to develop a person's competence in the form of attitudes and behaviors that occur in society. Process is when a person is influenced by a guided environment, particularly in a schooling environment, so that he can achieve social competence and develop his character. 
In the context of science and technology fiction novels research, education includes two forms namely education at home (informal) and education in institutions of higher learning (formal education). Based on the novel Klon (2015) by Idris Boi, non-formal education refers to education at home. In the novel, the author emphasizes religious education as the basis of human life through the portrayal of the character Haji Sulaiman, a father who is responsible for providing religious education to his children. Ever since childhood, his children have been taught to read Muqaddam, perform obligatory prayers in addition to circumcision rituals. This exemplary education succeeded in producing a generation that appreciates Allah. At the same time, his children also excelled academically. It is clear that the balance between religious and academic education can shape children into a generation of people with noble characters. The situation can be seen in the passage below:

If possible, never leave your nightly prayers, Din, even if it is only two rakaat. It is good to practice. It brings us closer to Allah SWT", advised his father.

(Klon: 133)

Apart from informal education, the Malay community also attaches great importance to formal education in institutions of higher learning. Institutions of higher learning play an important role in producing a workforce to meet the needs of an individual, their families as well as further contribute towards the development of the country. In the novel Klon (2015) by Idris Boi, it can be seen that Dr. Fakiruddin, who holds a Doctor of Philosophy degree in biochemistry, biotechnology and genetics, has contributed his services to developing the country's agricultural sector upon his return from abroad. Other than that, he also uses his experience and expertise of having worked in the United States to develop research and development programs in his own homeland. The situation can be proven through the passage below:

"The expertise at hand can be used to improve the quality of products in the country, especially the agricultural sector as well as to expand the country's R\&D program".

(Klon: 35-36)

Based on the example quoted above, the author indirectly illustrates the importance of producing human capital that specializes in science and technology to develop said field in Malaysia. The development of human capital as the core of the nation's civilization as stated by the former Prime Minister of Malaysia, Abdullah is vastly needed to produce and form a group of scientists or skilled workers who are knowledgeable, virtuous, skilled, competitive and resilient (Mazura et al., 2006). This is in line with scientific thinking, for which it produces a Malay community that has a mindset towards science and technology (Mohd, 2007).

\section{Malay Thought in the Aspect of Personality \\ (i) Spirit of Patriotism}

The concept of patriotism is often associated with love for the mother country. Following that, Maizatul et al (2007) patriotism is a feeling of deep love for one's homeland stemming from awareness of citizenship and loyalty to such an extent that a person is willing to sacrifice his life for their homeland. Based on that view, patriotism can also be defined as a person's feeling of love for their country to which they maintain their conduct while residing in another 
country. This point is crucial so that the country's image is not sullied or looked down upon by foreign countries.

This is clearly evident in the novel Klon (2015) by Idris Boi. When the spirit of patriotism is thoroughly permeated into the soul, they are willing to do anything to defend their beloved homeland. Such events can be seen through the patience shown by Dr. Fakiruddin who did not struggle despite being interrogated like a criminal by the FBI (Federal Bureau of Investigation). In fact, Dr. Fakiruddin was still able to smile and treat them politely. This can be seen in the passage below:

"Please, sit", Dr. Fakiruddin invited, seeking to be polite. That is the core of a nation's civilization. He is a Malay who is rich in courtesy. Despite working in a foreign land, cultural customs and manners must still be upheld. When in Rome, do as the Romans do.

(Klon: 71)

Based on the quotation above, the author indirectly highlights the spirit of patriotism embedded in Malaysians. The apparent patriotism towards one's country is characterized by the polite actions of Dr. Fakiruddin who did not respond to the harsh and rude actions of the FBI members who interrogated him like a criminal. He is always mindful to uphold the name of his country that is indeed famous for the nobility of its people's courtesy. This situation is also related to the opinion of Arba'ie, Che and Rafidah (2007) who stressed that loyalty is one of many important elements to produce a Malay society that posseses a spirit of patriotism. Loyalty to the King and Nation as enshrined within the third Rukun Negara can produce people who respect public property, respect the symbols of national sovereignty, abide by the law, are productive and strive to maintain the good name of the country. This is what the character values when expressing the spirit of patriotism to the country. Thus, the statement of patriotism displayed by Dr. Fakiruddin showed that the character has a double mindset that can be associated with the development of the human brain that steers a person towards excellence, glory, sustainability and intelligence (Mohd, 2007).

\section{(ii) Wisdom}

According to PRPM, wisdom refers to the subject of being wise or in respect to the usage of common sense. In the context of the study of science and technology fiction novels, wisdom refers to the intelligence of the characters in resolving conflicts or problems encountered. Based on the novel Klon (2015) by Idris Boi, this wisdom can be seen through the depiction of the character Dr. Fakiruddin who cleverly devises a strategy to escape from being killed by the FBI. Dr. Fakiruddin held his funeral at the Malaysian Embassy in Washington to conceal himself from the eyes of the $\mathrm{FBI}$ and the $\mathrm{CIA}$ (Central Intelligence Agency) of the United States so that they may discontinue their search for him. Dr. Fakiruddin's wit became even more prominent when he planned to change his identity in order to be able to get on a flight back to Malaysia. The event spotlighted the character of Dr. Fakiruddin as a Malay man who wisely planned and organized strategies to ensure the safety of both himself and Dr. Susan Lancaster so that they may return to Malaysia safely. The passage below describes the situation:

Dr. Susan Lancaster and Dr. Fakiruddin left the place once the coast was clear.

(Klon: 344) 
On account of the above quotation it is clear that the strategy devised by Dr. Fakiruddin reveals that he possesses the nature of wisdom by using creative thinking in solving the problems faced. So, exactly as stated by Mohd (2007), an individual with a creative mind is an individual who is imaginative, creative, innovative, optimistic, cheerful and always has a way to solve problems as well as make decisions in their daily life.

\section{Conclusion}

Research findings show that there are three types of Malay thought found in the novel Klon (2015) by Idris Boi. The first Malay thought was in terms of religion. In this novel, the religious aspect involves two forms of relationship, namely human relationships with Allah and human relationships with fellow human beings. The second Malay thought is in the aspect of education. There are two forms of education, namely non-formal education and formal education. The next Malay thought is the thought relating to character which describes the attitude of the Malays. Among them, Dr. Fakiruddin's patriotic spirit can be traced to his duty to the country by upholding his behavior while abroad. Additionally, the Malay thinking in terms of personality also describes the value of Malay wisdom in solving the problems faced. This study has also solved the research problems posed by some literary critics. It is clear that the novel Klon (2015) by Idris Boi displays several aspects of the Malay community's way of thinking that can be seen from various dimensions. Thus, this study is important in highlighting aspects of Malay thought in science and technology fiction novels.

\section{Acknowledgment}

The author would like to thank Universiti Putra Malaysia for sponsoring the UPM research grant GP-IPS/2021/9704700.

\section{References}

. (2005). Kamus Dewan Edisi Keenam. Kuala Lumpur: Dewan Bahasa dan Pustaka.

Arba'ie, S., Che, I., Siti, S., Rafidah, N. N. M. A. (2007). Bahasa Verbal dan Non-Verbal Sebagai Cerminan Masyarakat Dalam Novel-Novel Melayu. Jurnal Pengajian Melayu, Jil 18, 124.

Dewey, J. (1916). Democracy and Education. New York: Macmillan Co.

Farra, H. M., \& Nik, M. A. N. R. (2016). Pemikiran Kerohanian Dalam Cerpen Kanak-Kanak Pilihan Mutakhir Dan Kesan Positif Kepada Kanak-Kanak. PENDETA: Journal of Malay Language, Education and Literature, 7, 35 - 51. Retrieved from https://ejournal.upsi.edu.my/index.php/PENDETA/article/view/1190.

Idris, B. (2015). Klon. Kuala Lumpur: Utusan Publications \& Distributions Sdn Bhd.

Kneller, G. F. (1964). An Introduction to the Philosophy of Education. New York: John Wiley \& Sons.

Ku Hasnita, K. S. (2007). Pemupukan semangat patriotisme melalui proses sosialisasi politik. JATI-Journal of Southeast Asian Studies. Volume 12 (131-145).

Mochtar, B. (1994). Pendidikan dalam Pembangunan. Jakarta: IKIP Muhammadiyah Jakarta Press.

Mohd, Y. H. (2007). Teori Pendidikan Pemikiran Global. Penerbit Tanjong Malim Universiti Pendidikan Sultan Idris.

Rafidah, N. N. M. A., Siti, S., \& Arba'ie, S. (2010). Warisan Budaya Berfikir Lambang Kecendekiaan Minda Melayu dalam Sastera Rakyat Kanak-kanak. Jurnal ASWARA. $5(1), 18-27$. 
Nisah, H. (2014). Mencari Akar Fiksyen Sains Melayu. Dewan Sastera, 9-15.

Noor, H. H. A., \& Salmah, J. N. M. (2019). Pemikiran dalam Novel Siber Kasih Darmia dari Aspek Teori Estetika Bersepadu. Malaysian Journal of Science Social and Humanities Vol 4, Issue 4. 46-54.

Normaizatul, A. A., \& Halis, A. M. H. (2019). Pemikiran Islam Dalam Konteks Sosioekonomi Dalam Kumpulan Cerpen Cahaya Pelita Nurani. Jurnal Pengajian Melayu, Jilid 30.

Nurul, H. C. S. (2015). Pemikiran Islam dalam 'Ayn Karya Kemala. Jurnal Melayu. Bil 14 (2).240-259.

Poerdawinta, W. J. S. (1986). Kamus Besar Umum Indonesia. Jakarta: Balai Pustaka.

PRPM. (2021). Dilayari pada 2021 di laman web http://prpm.dbp.gov.my.

Shahnon, A. (1987). Gubahan Novel. Kuala Lumpur: Dewan Bahasa dan Pustaka.

Wan, H. W. T. (2010). Rumpun Melayu: Minoriti dan Dispora. Kuala Lumpur: Universiti Pertahanan Nasional Malaysia.

Wellek, R., \& Warren, A. (1988). Teori Kesusasteraan. Terj. Wong Seng Tong. Kuala Lumpur: Dewan Bahasa dan Pustaka. 